\title{
Fungi on stems and twigs in initial and advanced stages of dieback of European ash (Fraxinus excelsior) in Poland
}

\author{
Tadeusz Kowalski $^{1}$ - Wojciech Kraj ${ }^{1} \cdot$ Bartłomiej Bednarz $^{1}$
}

Received: 5 August 2015/Revised: 14 March 2016/Accepted: 20 March 2016/Published online: 1 April 2016

(c) The Author(s) 2016. This article is published with open access at Springerlink.com

\begin{abstract}
F. excelsior is affected by dieback in the major part of its natural geographical range in Europe, which results in economic and ecological losses. The disease is caused by the ascomycetous fungus Hymenoscyphus fraxineus, a pathogen introduced to Europe most probably from East Asia. This paper presents data on fungi identified on F. excelsior trees representing two different stages of ash dieback in Poland. Fungal communities were identified in initial necrotic lesions on living stems and twigs using the classical method of isolation on malt extract agar and morphological and molecular analyses. In dead apical parts of stems and twigs, fungi were identified by microscopic analyses of fruit bodies formed in situ. Seventy-one fungal taxa were found in 720 samples with symptoms of initial or advanced necrosis. The most common fungus detected in initial necrotic lesions in each forest site was Hymenoscyphus fraxineus (59.2\% of analysed samples). Other frequently isolated fungi included Alternaria alternata, Diaporthe eres, Diplodia mutila, Fusarium avenaceum, $F$. lateritium and Phomopsis spp. Fruit bodies on dead apical parts of stems and twigs were produced mostly by Diaporthe eres, Diplodia mutila, Lophiostoma corticola, Phomopsis spp., Sirodothis sp. and Valsa cypri. Fungal communities from different sites were similar, as shown by high Sørensen similarity index values. Greatest variation in fungal community structure at the initial necrotic stage was realized by $D$. mutila and $F$. avenaceum, and at the
\end{abstract}

Communicated by Christian Ammer.

Tadeusz Kowalski

rltkowal@cyf-kr.edu.pl

1 Institute of Forest Ecosystem Protection, University of Agriculture, Al. 29-Listopada 46, 31-425 Cracow, Poland advanced necrotic stage by D. eres, D. mutila and Phomopsis spp. Data show a close affinity of certain fungi to site, suggesting geographical relatedness. The ecological effects of distribution of the invasive $H$. fraxineus and of other fungi sporulating on diseased ash trees in Europe are discussed.

Keywords Ash dieback · Fungal communities . Hymenoscyphus fraxineus

\section{Introduction}

Fraxinus excelsior is the most widely distributed native ash species in Europe (Wardle 1961; Wallander 2008; Dobrowolska et al. 2011; Clark 2013). Its successful expansion resulted mainly from anthropogenic factors and heterogeneous environmental conditions. It may also have benefited from some ecophysiological attributes that made it less susceptible than many other broadleaved tree species to attack over large areas by dangerous pests and pathogens (Wardle 1961; Marigo et al. 2000; Amar et al. 2010; Chen 2012; Pautasso et al. 2013; Gross et al. 2014). The situation has changed, however, in the last 20 years since the early 1990s large-scale dieback of $F$. excelsior has been found and observed increasingly in Poland and Lithuania (Kowalski 2001; Przybył 2002; Lygis et al. 2005). Subsequently, F. excelsior dieback spread towards south, west and northern Europe and has reached epidemic level in most European countries, including Great Britain where it was first observed in 2012 (Husson et al. 2011; Timmerman et al. 2011; Pautasso et al. 2013; Gross et al. 2014).

Studies on the causal agent of $F$. excelsior dieback took place over a few years. First, the genus Chalara was reported as the causal agent of disease and its microscopic 
features were presented (Kowalski 2001). The fungus was described as a new anamorphic ascomycetous species, Chalara fraxinea (Kowalski 2006). Its teleomorph, based on morphological features, was initially designated as Hymenoscyphus albidus (Kowalski and Holdenrieder 2009a). Further research based on DNA sequences of isolates from Switzerland and other European countries revealed that $H$. albidus represents an aggregate of two clearly delimited species (Queloz et al. 2011). One was related to the non-pathogenic $H$. albidus sensu stricto, which had been known in Europe since 1850 (Kowalski and Holdenrieder 2009a; Baral and Bemmann 2014). The second was described as a new cryptic species, $H y$ menoscyphus pseudoalbidus, with Ch. fraxinea as its anamorph (Queloz et al. 2011). A new taxonomic designation was made by Baral et al. (2014), who stated that under the rules for the naming of fungi with pleomorphic life cycles, adopted in July 2011 (Hawksworth 2014), the nomenclaturally correct name for the fungus causing the current ash dieback in Europe is Hymenoscyphus fraxineus with the basionym Chalara fraxinea, and Hymenoscyphus pseudoalbidus as a taxonomic synonym of $H$. fraxineus.

Ash trees are infected by wind-dispersed ascospores of $H$. fraxineus produced in summer in apothecia on old leaf debris from the previous year and sporadically at the base of seedling stems (Kowalski et al. 2010; Kirisits et al. 2012; Gross et al. 2014; Kraj and Kowalski 2014). Disease symptoms include necrotic lesions on leaves, twigs and branches and sporadically on stem bases and roots, followed by wilting and premature shedding of leaves and dieback of tips, whole twigs and branches (Kowalski 2001; Chandelier et al. 2010; Schumacher et al. 2010; Gross et al. 2014). The disease affects trees of all ages. Disease progress is, however, slower in older than in younger trees (Kowalski and Czekaj 2010; Skovsgaard et al. 2010; McKinney et al. 2011; Kirisits and Freinschlag 2012). Ultimately, the disease leads to the death of single trees and whole stands, which has consequences to the survival and distribution of F. excelsior in Europe (Pautasso et al. 2013).

The previous studies showed that shoots of declining ash in Poland are colonized, in addition to $H$. fraxineus, by other species of fungi, like generally in every diseased and symptomatic plant tissue (Kowalski 2001, 2006; Przybył 2002; Kowalski and Łukomska 2005; Kowalski and Holdenrieder 2008; Gross et al. 2014). Further systematic mycological analyses are being made in Poland for recognition of the fungal communities in symptomatic stems and twigs of $F$. excelsior trees at different stages of disease progress.

Recognition of the structure of fungal communities in initial necrotic lesions on stems and twigs was the first objective of this study. Such analysis was expected to: (1) determine the frequency of $H$. fraxineus as the potential primary causal agent of $F$. excelsior dieback; (2) identify fungal species that benefit from earlier, primary infection by $H$. fraxineus or initially colonize the tissue independently and cause lesions similar to those of $H$. fraxineus; and (3) create the basis for studies on interactions between $H$. fraxineus and other fungal colonizers that contribute to progress of necrosis and disease (Bengtsson et al. 2014). Relationships between host and fungi are particularly important in relation to global warming, with consequences for host and pathogen physiology, reproduction, survival, spatial and temporal distribution, resource availability and competition (Clark 2013).

Another important objective was the detection and identification of fungi that form fruit bodies on the dead parts of stems and twigs. Since fruit bodies are the main reservoir of inoculum, dead tissues might represent a risk for the health of $F$. excelsior and other tree species, particularly if diseased or dead trees are left for nutrient cycling and sustainable development of the forest (Lassauce et al. 2011; Pautasso et al. 2013). Recognition of the form and intensity of fructification and sporulation may help to create environmentally appropriate, and suitable management practices in tree stands with $F$. excelsior. To characterize the fungal community, numerous samples originating from several sites of Poland, where F. excelsior showed dieback symptoms, were examined. The research covers a continuous 6-year period of investigation and so must be considered as unique in fungal community studies on European ash. The study began soon after the first description of the fungus Chalara fraxinea as the main causal agent of ash dieback (Kowalski 2006).

\section{Materials and methods}

\section{Study sites and sampling}

Study material was collected in six forest sites (five forest districts and one national park). Five of the sites were in southern and one in northern Poland (Fig. 1). At each site, four separate groups of young $F$. excelsior trees, 1-3 m high, with dieback symptoms, within a radius of $5 \mathrm{~km}$, were chosen at random. The ash was growing mostly under mixed stands including fresh, mixed fresh or wet deciduous forests or alder-ash wet forest, and less often in open areas. Average annual temperature, average annual precipitation and the height of sites above mean sea level are given in Table 1.

One 40-cm-long section of stem or twig, with visible external initial necrotic lesion, was collected from each of 15 living ash trees in each of the four plots at each site based on a single sampling in June 2007-2012 (Tables 2, 3 ). The necrotic lesions on the sample material were typical 


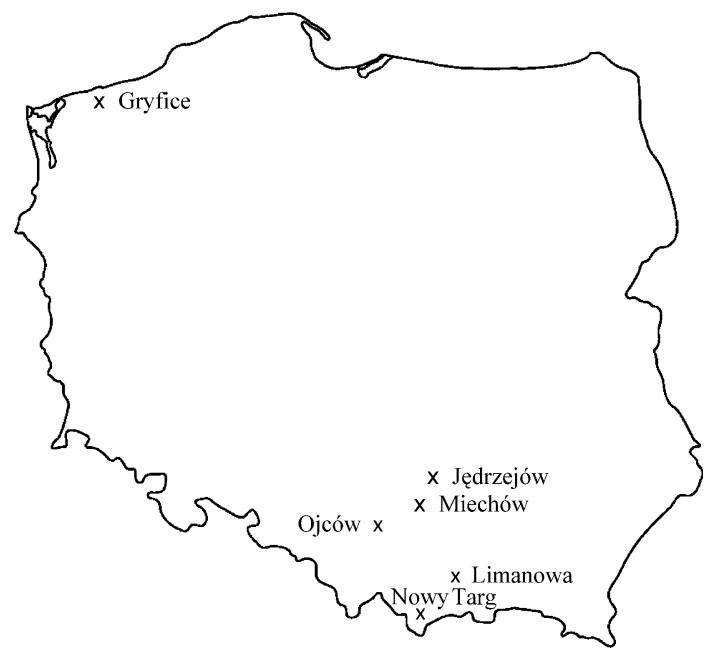

Fig. 1 Schematic map of Poland showing forest sites sampled for stems and twigs of $F$. excelsior

of $H$. fraxineus infection; they were lens-shaped and located on stems and twigs at the base of dead side shoots and sporadically around buds (Kowalski and Holdenrieder 2008, 2009b). The bark was evenly light brown or light brown stained with dark strips, rarely evenly dark brown, with no fruit bodies. Sporadically, necrosis was accompanied by leaf wilt in the distal parts of the tree. The lensshaped lesions, which were sunken in comparison with the surrounding tissues of the living stems, suggesting their long-term development, were not included in the study (Kowalski and Holdenrieder 2008).

At the same forest sites, in each of four plots of each site, within the period of August-September 2007-2012, the dead apical part of the main stem or twig (24-142 cm long) was collected once from each of 15 living but symptomatic ashes (Tables 2, 4). The bark on most samples was still uniformly attached to the wood. Areas with possible initial necrosis of bark, resulting from typical infection by $H$. fraxineus followed by girdling of stems or twigs, were observed on $80 \%$ of samples. Bark in those areas was discoloured, sunken and cracked, with longitudinal scratches. Such symptoms were absent on the remaining $20 \%$ of samples, particularly where they had necrotic bark that was broken or peeling, often exposing the wood or contributing to canker formation. Fungal fruit bodies were often present on the bark surface. The samples were placed separately in plastic bags and brought to the laboratory for analysis.

Sixty samples of each type were collected from each forest site, $80 \%$ of which originated from main stems and $20 \%$ from twigs. A total 720 samples of both types were analysed (Tables 2, 3, 4).

\section{Isolation and identification of fungi from initial necrotic lesions}

Fungal isolations from initial necrotic lesions were performed within 24-72 $\mathrm{h}$ from collection of samples, which were stored meanwhile at $4{ }^{\circ} \mathrm{C}$. Stem or twig sections with necrotic lesions were surface-sterilized by soaking first for $1 \mathrm{~min}$ in $96 \%$ ethanol, then for $5 \mathrm{~min}$ in a solution of sodium hypochlorite (approx. $4 \%$ available chlorine) and finally for $30 \mathrm{~s}$ in $96 \%$ ethanol. After drying in layers of blotting paper and removal of superficial tissue, six pieces consisting of inner bark and wood tissue $(5 \times 2 \times 2 \mathrm{~mm})$ were cut out and placed on the surface of malt extract agar (MEA; $20 \mathrm{~g}^{-1}$ malt extract (Difco; Sparks, MD, USA), $15 \mathrm{~g} \mathrm{l}^{-1}$ agar Difco supplemented with $100 \mathrm{mg} \mathrm{l}^{-1}$ streptomycin sulphate) in Petri dishes (diam. $9 \mathrm{~cm}$ ). In total, isolations were made from 2160 pieces from 360 necrotic lesions (Table 2). The incubation took place at $20{ }^{\circ} \mathrm{C}$ in darkness. All Petri dishes were examined every 3-7 days for at least 6 weeks. Different fungal taxa detected on different tissue pieces on the same agar plate were isolated and re-grown on new agar plates. All isolated fungi were grouped into morphotypes. Morphotypes were identified on the basis of culture structure, sporulation and comparison with the collection of standard morphotypes deposited at the Department of Forest Pathology, Mycology and Tree Physiology, University of Agriculture in Kraków, Poland.

In addition, one of each morphotype was identified by molecular means. Therefore, total genomic DNA was

Table 1 Characteristics of study sites

\begin{tabular}{llllll}
\hline Forest site & Coordinates & Elevation a.s.1. [m] & $\begin{array}{l}\text { Mean annual } \\
\text { temperature }\left({ }^{\circ} \mathrm{C}\right) \\
\text { average from } \\
2010 \text { to } 2012\end{array}$ & $\begin{array}{l}\text { Number of days } \\
\text { with temp. }>25{ }^{\circ} \mathrm{C} \\
\text { in 2010-2012 }\end{array}$ & $\begin{array}{l}\text { Annual precipitation } \\
\text { sum }(\mathrm{mm}) \text { average } \\
\text { from } 2010 \text { to } 2012\end{array}$ \\
\hline Gryfice & $53^{\circ} 54^{\prime} \mathrm{N} 15^{\circ} 11^{\prime} \mathrm{E}$ & 30 & 8,3 & 5 & 755 \\
Jędrzejów & $50^{\circ} 38^{\prime} \mathrm{N} 20^{\circ} 17^{\prime} \mathrm{E}$ & 240 & 7,9 & 3 & 683 \\
Miechów & $50^{\circ} 21^{\prime} \mathrm{N} 20^{\circ} 02^{\prime} \mathrm{E}$ & 330 & 7,9 & 4 & 622 \\
Ojców & $50^{\circ} 13^{\prime} \mathrm{N} 19^{\circ} 49^{\prime} \mathrm{E}$ & 340 & 8,3 & 5 & 830 \\
Limanowa & $49^{\circ} 42^{\prime} \mathrm{N} 20^{\circ} 25^{\prime} \mathrm{E}$ & 400 & 7,9 & 6 & 982 \\
Nowy Targ & $49^{\circ} 29^{\prime} \mathrm{N} 20^{\circ} 01^{\prime} \mathrm{E}$ & 580 & 5,9 & 0 & 987
\end{tabular}


Table 2 Fungi detected after isolation from initial necrotic lesions and formation of fruit bodies on dead apical parts of stems and twigs

\begin{tabular}{|c|c|c|c|c|}
\hline Fungi & $\begin{array}{l}\text { Genbank } \\
\text { accession no. }\end{array}$ & $\begin{array}{l}\text { Primer used for } \\
\text { amplification }\end{array}$ & $\begin{array}{l}\text { Number }(\%) \text { in initial } \\
\text { necrotic lesions }\end{array}$ & $\begin{array}{l}\text { Number }(\%) \text { in dead } \\
\text { stems or twigs }\end{array}$ \\
\hline Alternaria alternata (Fr.) Keissl. & KT0 04593 & ITS1F & $50(13.9)$ & $4(1.1)$ \\
\hline Arthrinium arundinis (Corda) Dyko \& B. Sutton & KT0 04564 & ITS1 & $1(0.3)$ & \\
\hline $\begin{array}{l}\text { Aureobasidium pullulans (de Bary \& Löw.) G. } \\
\text { Arnaud }\end{array}$ & KT0 04589 & ITS1F & $11(3.1)$ & \\
\hline Bloxamia cf. truncata Berk. \& Broome & & & & $1(0.3)$ \\
\hline Cadophora sp. 1 & KT0 04571 & ITS1F & $1(0.3)$ & \\
\hline Cadophora sp. 2 & KT0 04566 & ITS1F & $4(1.1)$ & \\
\hline Camarosporium orni Henn. & & & & $5(1.4)$ \\
\hline Chaetomium globosum Kunze & KT0 04591 & ITS1F & $1(0.3)$ & \\
\hline $\begin{array}{l}\text { Cladosporium cladosporioides (Fresen.) G.A. de } \\
\text { Vries }\end{array}$ & KT0 04588 & ITS1F & $3(0.8)$ & $1(0.3)$ \\
\hline Coleophoma empetri (Rostr.) Petr. & & & & $8(2.2)$ \\
\hline Cryptosphaeria eunomia (Fr.) Fuckel & & & & $9(2.5)$ \\
\hline Cyphellophora sessilis (de Hoog) Réblová \& Unter. & KT0 04582 & ITS1F & $2(0.6)$ & \\
\hline Cytospora spp. & & & $3(0.8)$ & $9(2.5)$ \\
\hline Dactylaria sp. & KT0 04561 & ITS1F & $1(0.3)$ & \\
\hline Diaporthe eres Nitschke & KT0 04549 & ITS1 & $79(21.9)$ & $74(20.6)$ \\
\hline Diatrype stigma (Hoffm.) Fr. & KT0 04563 & ITS1 & $2(0.6)$ & \\
\hline Didymosphaeria acerina Rehm & & & & $3(0.8)$ \\
\hline Diplodia mutila (Fr.) Mont. & KT0 04548 & ITS1 & $61(16.9)$ & $119(33.1)$ \\
\hline Diplodia seriata De Not. & KT0 04551 & ITS1 & $5(1.4)$ & $4(1.1)$ \\
\hline Diplodina $c f$. acerina (Pass.) B. Sutton & & & & $1(0.3)$ \\
\hline $\begin{array}{l}\text { Dothiorella sarmentorum (Fr.) A.J.L. Phillips, A. } \\
\text { Alves \& J. Luque }\end{array}$ & KT0 04552 & ITS1 & $4(1.1)$ & $6(1.7)$ \\
\hline Dothiorella sp. & & & & $9(2.5)$ \\
\hline Encoelia furfuracea (Roth) P. Karst. & & & & $4(1.1)$ \\
\hline Epicoccum nigrum Link & KT0 04587 & ITS1F & $6(1.7)$ & $4(1.1)$ \\
\hline Fusarium avenaceum (Fr.) Sacc. & KT0 04586 & ITS1F & $43(11.9)$ & $3(0.8)$ \\
\hline Fusarium lateritium Nees & KT0 04553 & ITS1 & $54(15.0)$ & $3(0.8)$ \\
\hline Fusarium solani (Mart.) Sacc. & KT0 04555 & ITS1 & $1(0.3)$ & \\
\hline $\begin{array}{l}\text { Gloeosporidiella turgida (Berk. \& Broome) B. } \\
\text { Sutton }\end{array}$ & & & & $6(1.7)$ \\
\hline $\begin{array}{l}\text { Hymenoscyphus fraxineus (T. Kowalski) Baral, } \\
\text { Queloz \& Hosoya }\end{array}$ & KT0 04554 & ITS1 & $213(59.2)$ & $8(2.2)$ \\
\hline Hypoxylon serpens (Pers.) J. Kickx & KT0 04590 & ITS1F & $5(1.4)$ & \\
\hline Lecytophora sp. & KT0 04574 & ITS1F & $3(0.8)$ & \\
\hline $\begin{array}{l}\text { Lophiostoma corticola (Fuckel) E.C.Y. Liew, } \\
\text { Aptroot \& K.D. Hyde }\end{array}$ & KT0 04559 & ITS1 & $8(2.2)$ & $31(8.6)$ \\
\hline Melanomma pulvis-pyrius (Pers.) Fuckel & & & & $3(0.8)$ \\
\hline Microdiplodia microsporella Allesch. & & & & $4(1.1)$ \\
\hline Mollisia cf. cinerea (Batsch) P. Karst. & & & & $1(0.3)$ \\
\hline Nectria cinnabarina (Tode) Fr. & & & & $5(1.4)$ \\
\hline Neonectria coccinea (Pers.) Rossman \& Samuels & & & & $1(0.3)$ \\
\hline Neonectria galligena (Bres.) Rossman \& Samuels & & & & $6(1.7)$ \\
\hline Neonectria sp. & & & & $3(0.8)$ \\
\hline $\begin{array}{l}\text { Paraconiothyrium sporulosum (W. Gams \& } \\
\text { Domsch) Verkley }\end{array}$ & KT0 04560 & ITS1F & $5(1.4)$ & $2(0.6)$ \\
\hline Peniophora cinerea (Pers.) Cooke & & & & $3(0,8)$ \\
\hline Periconia byssoides Pers. & KT0 04592 & ITS1F & $1(0.3)$ & \\
\hline
\end{tabular}


Table 2 continued

\begin{tabular}{|c|c|c|c|c|}
\hline Fungi & $\begin{array}{l}\text { Genbank } \\
\text { accession no. }\end{array}$ & $\begin{array}{l}\text { Primer used for } \\
\text { amplification }\end{array}$ & $\begin{array}{l}\text { Number }(\%) \text { in initial } \\
\text { necrotic lesions }\end{array}$ & $\begin{array}{l}\text { Number }(\%) \text { in dead } \\
\text { stems or twigs }\end{array}$ \\
\hline Phoma exigua Desm. & KT0 04579 & ITS1F & $9(2.5)$ & $5(1.4)$ \\
\hline Phoma herbarum Westend. & KT0 04577 & ITS1F & $1(0.3)$ & \\
\hline Phoma macrostoma Mont. & KT0 04572 & ITS1F & $1(0.3)$ & \\
\hline $\begin{array}{l}\text { Phoma multirostrata (P.N. Mathur, S.K. Menon \& } \\
\text { Thirum.) Dorenb. \& Boerema }\end{array}$ & KT0 04594 & ITS1F & $1(0.3)$ & \\
\hline Phoma sp. & KT0 04556 & ITS1 & $4(1.1)$ & $2(0.6)$ \\
\hline Phomopsis spp. & & & $63(17.5)$ & $56(15.6)$ \\
\hline Plectosphaerella cucumerina (Lindf.) W. Gams & KT0 04576 & ITS1 & $2(0.6)$ & \\
\hline Pleurophoma pleurospora (Sacc.) Höhn. & & & & $11(3.1)$ \\
\hline Rutstroemia firma (Pers.) P. Karst. & KT0 04575 & ITS1F & & $1(0.3)$ \\
\hline Sarocladium strictum (W. Gams) Summerb. & KT0 04567 & ITS1F & $2(0.6)$ & \\
\hline $\begin{array}{l}\text { Simplicillium lamellicola (F.E.V. Sm.) Zare \& W. } \\
\text { Gams }\end{array}$ & KT0 04573 & ITS1F & $2(0.6)$ & \\
\hline Sirodothis sp. & & & & $19(5.3)$ \\
\hline Sistotrema brinkmannii (Bres.) J. Erikss. & KT0 04583 & ITS1F & $1(0.3)$ & \\
\hline Stictosepta cupularis Petr. & & & & $4(1.1)$ \\
\hline Teichospora obducens (Schumach.) Fuckel & & & & $7(1.9)$ \\
\hline Trimmatostroma sp. & & & & $1(0.3)$ \\
\hline Valsa ambiens (Pers.) Fr. & KT0 04550 & ITS1 & $1(0.3)$ & $4(1.1)$ \\
\hline Valsa cypri (Tul.) Tul. \& C. Tul. & KT0 04557 & ITS1F & $14(3.9)$ & $109(30.3)$ \\
\hline Xylaria sp. 1 & KT0 04580 & ITS1F & $2(0.6)$ & \\
\hline Xylaria sp. 2 & KT0 04562 & ITS1F & $1(0.3)$ & \\
\hline Unidentified Ascomycota 3687/1 & KT0 04565 & ITS1F & $1(0.3)$ & \\
\hline Unidentified Ascomycota 6235 & KT0 04568 & ITS1F & $1(0.3)$ & \\
\hline Unidentified Ascomycota 6241/2 & KT0 04569 & ITS1F & $1(0.3)$ & \\
\hline Unidentified Ascomycota 6294 & KT0 04570 & ITS1F & $2(0.6)$ & \\
\hline Unidentified Ascomycota 6553/2 & KT0 04578 & ITS1F & $2(0.6)$ & \\
\hline Unidentified Ascomycota 6757 & KT0 04581 & ITS1F & $2(0.6)$ & \\
\hline Unidentified Ascomycota 6778 & KT0 04584 & ITS1F & $2(0.6)$ & \\
\hline Unidentified Ascomycota 6835 & KT0 04585 & ITS1F & $2(0.6)$ & \\
\hline Unidentified Ascomycota 20302 & KT0 04558 & ITS1 & $1(0.3)$ & \\
\hline Number of samples analysed & & & 360 & 360 \\
\hline
\end{tabular}

extracted from mycelium using the Genomic Mini AX Plant (A \& A Biotechnology, Gdańsk, Poland) following the manufacturer's instructions. DNA samples were dissolved in TE buffer (10 mM Tris- $\mathrm{HCl}, 1 \mathrm{mM}$ EDTA) to get a concentration of $10 \mathrm{ng} \mu \mathrm{l}^{-1}$ and stored at $-20^{\circ} \mathrm{C}$. The ITS $1 / 2$ rDNA was amplified by PCR with the use of ITS 1F (5' CTT GGT CAT TTA GAG GAA GTA A) and ITS 4 (5' TCC TCC GCT TAT TGA TAT GC) primers (White et al. 1990; Gardes and Bruns 1993). The $50 \mu \mathrm{l}$ PCR mixture consisted of PCR buffer, $2 \mathrm{mM} \mathrm{MgCl}_{2}$, $0.2 \mathrm{mM}$ deoxyribonucleoside triphosphates (dNTPs, MBI Fermentas, Burlington, Canada), $1 \mu \mathrm{M}$ of each primer, $1 \mathrm{U}$ of Dream Taq Green polymerase (MBI Fermentas, Burlington, Canada) and $50 \mathrm{ng}$ of DNA. Cycling conditions were: an initial denaturation at $95^{\circ} \mathrm{C}$ for $5 \mathrm{~min}$, followed by 36 cycles of denaturation at $95{ }^{\circ} \mathrm{C}$ for $1 \mathrm{~min}$, annealing at $56^{\circ} \mathrm{C}$ for $45 \mathrm{~s}$ and elongation at $72{ }^{\circ} \mathrm{C}$ for $3 \mathrm{~min}$, and a final extension at $72{ }^{\circ} \mathrm{C}$ for $8 \mathrm{~min}$. For fungi that were not amplified with ITS $1 \mathrm{~F}$, primers ITS $1\left(5^{\prime} \mathrm{TCC}\right.$ GTA GGT GAA CCT GCG G) (White et al. 1990) and ITS 4 were used (Table 2), and the annealing temperature was changed to $51{ }^{\circ} \mathrm{C}$. The PCR products were checked by electrophoresis of $5 \mu \mathrm{l}$ of product in $1.5 \%$ agarose gel containing fluorescent Midori Green DNA Stain (Nippon Genetics Co. Ltd, Tokyo, Japan). PCR products were purified using the MinElute PCR purification kit (Qiagen, Crawley, UK). DNA was sequenced using the BigDye1 Terminator v3.1 Cycle Sequencing Kit (AB Applied Biosystems, Foster City, CA 94404, USA) and primers ITS $1 \mathrm{~F}$ or ITS 1 . The purified products were run at the DNA 
Table 3 Fungi with frequency $>5 \%$ in initial necrotic lesions on living stems and twigs of $F$. excelsior

\begin{tabular}{|c|c|c|c|c|c|c|c|}
\hline \multirow[t]{2}{*}{ Fungi } & \multicolumn{7}{|c|}{ Frequency $(\%)$ in forest site } \\
\hline & Gryfice & Jędrzejów & Miechów & Ojców & Limanowa & Nowy Targ & Total \\
\hline Alternaria alternata & 15.0 & 13.3 & 3.3 & 25.0 & 10.0 & 16.7 & 13.9 \\
\hline Diaporthe eres & 18.3 & 13.3 & 23.3 & 26.7 & 10.0 & 40.0 & 21.9 \\
\hline Diplodia mutila & 43.3 & 8.3 & 16.7 & 18.3 & 11.7 & 3.3 & 16.9 \\
\hline Fusarium avenaceum & 8.3 & 1.7 & 8.3 & 8.3 & 10.0 & 35.0 & 11.9 \\
\hline Fusarium lateritium & 15.0 & 8.3 & 16.7 & 16.7 & 8.3 & 25.0 & 15.0 \\
\hline Hymenoscyphus fraxineus & 65.0 & 61.7 & 60.0 & 56.7 & 68.3 & 43.3 & 59.2 \\
\hline Phomopsis spp. & 13.3 & 13.3 & 18.3 & 18.3 & 11.7 & 30.0 & 17.5 \\
\hline Number of taxa detected ${ }^{a}$ & 23 & 23 & 25 & 20 & 21 & 22 & 48 \\
\hline Number of samples analysed & 60 & 60 & 60 & 60 & 60 & 60 & 360 \\
\hline Year of sampling & 2010 & 2007 & 2008 & 2012 & 2011 & 2009 & 2007-2012 \\
\hline
\end{tabular}

a Total for each forest site, regardless of frequency

Table 4 Fungi with frequency $>5 \%$ on apical parts of stems and twigs of $F$. excelsior detected by formation of fruit bodies

\begin{tabular}{|c|c|c|c|c|c|c|c|}
\hline \multirow[t]{2}{*}{ Fungi } & \multicolumn{7}{|c|}{ Frequency $(\%)$ of samples from forest site } \\
\hline & Gryfice & Jędrzejów & Miechów & Ojców & Limanowa & Nowy Targ & Total \\
\hline Diaporthe eres & 10.0 & 11.7 & 20.0 & 13.3 & 26.7 & 41.7 & 20.6 \\
\hline Diplodia mutila & 61.7 & 46.7 & 18.3 & 40.0 & 28.3 & 3.3 & 33.1 \\
\hline Lophiostoma corticola & 3.3 & 6.7 & 10.0 & 10.0 & 15.0 & 6.7 & 8.6 \\
\hline Phomopsis spp. & 3.3 & 5.0 & 20.0 & 15.0 & 21.7 & 28.3 & 15.6 \\
\hline Sirodothis sp. & 1.7 & 8.3 & 3.3 & 5.0 & 8.3 & 5.0 & 5.3 \\
\hline Valsa cypri & 16.7 & 40.0 & 38.3 & 36.7 & 31.7 & 18.3 & 30.3 \\
\hline Number of taxa detected ${ }^{\mathrm{a}}$ & 18 & 18 & 26 & 25 & 22 & 15 & 39 \\
\hline Number of samples analysed & 60 & 60 & 60 & 60 & 60 & 60 & 360 \\
\hline Year of sampling & 2010 & 2007 & 2008 & 2012 & 2011 & 2009 & 2007-2012 \\
\hline
\end{tabular}

${ }^{a}$ Total from each forest site, regardless of frequency

sequencing facility of Macrogen Europe (Amsterdam, the Netherlands). Sequences were identified by comparison with reference sequences in NCBI GenBank using Geneious 6.1.8 software (Biomatters, Auckland, New Zealand) (Kearse et al. 2012) and BLAST (Basic Local Alignment Search Tool, Altschul et al. 1997). Each sequence was identified to the lowest taxonomic rank possible. Sequences with 97-100\% similarity were identified to species and with 91-97\% similarity to genus (Glen et al. 2001); however, the morphological analyses have been also taken into account. Sequences of representative isolates were deposited in GenBank (Table 2).

\section{Identification of fungi on dead apical parts of stems and twigs}

Identification was made by macro- and microscopic analysis of fruit bodies and sporulation formed on collected samples. For microscopic analysis, hand-cut sections and 1-3 slides were prepared from each fruit body. Observations were made with a Zeiss V12 Discovery stereomicroscope (Zeiss, Göttingen, Germany), and with a Zeiss Axiophot light microscope using differential interference contrast (DIC) illumination and an AxioCam MRc5 and HR3 cameras. Fungi were classified and identified to the lowest taxonomic rank on the basis of anatomical and morphological features using the mycological keys or monographs (Grove 1935; Ellis 1971; Domsch et al. 1980; Sutton 1980; Sivanesan 1984; Ellis and Ellis 1985; Spielman 1985; Uecker 1988; Boerema et al. 2004; de Gruyter et al. 2010).

\section{Statistical analyses}

The occurrence frequency of an individual taxon was expressed as the percentage of colonized samples 
(Tables 2, 3, 4). Sørensen similarity indices (Magurran 1988) were used to compare the total fungal communities from different forest sites as well as between initial necrotic lesions and dead tops of stems. The exploration of multivariate structure of contingency (frequency) table was done using correspondence analysis (CA) implemented in package Statistica 10 (Statsoft Inc. 2011). CA technique analyse frequency data and construct directions in the space that explain inertia (a total Pearson Chi-square divided by the total number of observations). The calculation of the Chi-square value requires the condition fulfilment of minimum number of observations, which have been done as the result of the adoption of the $5 \%$ frequency threshold (Tables 3, 4). The structure of objects was presented in standardized coordinate system which make easier to recognize the relationship between the forest site (variables) and fungal taxa (cases) (Figs. 2, 3).

\section{Results}

There were 48 fungal taxa identified, represented by 2074 fungal isolates from 360 samples of initial necrotic lesions. Sixteen fungal taxa were found in only one sample (Table 2). The number of fungal taxa in each forest site ranged from 20 (Ojców) to 25 (Miechów) (Table 3). Sørensen similarity indices for fungal communities between sites were high with an average of 0.82 (Table 5). Most taxa were identified to species $(69.0 \%)$ or genus $(18.3 \%)$. Most species belonged to the Ascomycota (98.6\%). Only Sistotrema brinkmannii, represented by one isolate, belonged to the Basidiomycota (Table 2).

The frequency of $H$. fraxineus ranged from $43.3 \%$ at the Nowy Targ site to $68.3 \%$ at the Limanowa site (Table 3 ). The growth rate of $H$. fraxineus colonies isolated from bark or wood placed on agar medium was low. However, the inhibition zone, which often formed around a colony, restricted growth of accompanying, faster-growing fungi. Colonies formed by the fungus in vitro were orange, whitish or whitish grey, sometimes with black stromatic structures. Phialospores produced on phialophores appeared abundantly, particularly after longer incubation at a low temperature $\left(5^{\circ} \mathrm{C}\right)$.

Despite much interspecific variation, six other taxa, Alternaria alternata, Diaporthe eres, Diplodia mutila, Fusarium avenaceum, F. lateritium and Phomopsis spp., were present in more than $5 \%$ of samples from all six forest sites (Tables 2, 3). The frequency of $A$. alternata differed between sites. This fungus was seven times more frequent at the Ojców site than at the Miechów site (Table 3). Diaporthe eres was the most common representative of the Diaporthe (Phomopsis) complex (Table 2). Its highest and lowest frequencies were recorded at the
Nowy Targ and Limanowa sites, respectively (Table 3). In vitro, this fungus formed only its anamorphic stage, Phomopsis velata $(=P h$. oblonga), which was recognizable by its two kinds of conidia: the ellipsoid alpha conidia and hamate beta conidia. The frequency of Phomopsis spp. ranged from 11.7 to $30.0 \%$ (Table 3 ). The highest and lowest frequencies of $D$. mutila were recorded at the Gryfice and Nowy Targ sites (Table 3). Other anamorphic species represented Botryosphaeria teleomorph identified in initial necrotic lesions included Dothiorella sarmentorum and Diplodia seriata (Table 2). Among the other fungi, Aureobasidium pullulans, Lophiostoma corticola, Phoma exigua and Valsa cypri were the most frequent (Table 2). Endophytic fungi from Xylariaceae were represented by Hypoxylon serpens and two species of the genus Xylaria. Only Chaetomium globosum formed ascomata with ascospores in vitro. Other ascomycetous species did not fructify in vitro or formed only conidia. Taxa classified as Cytospora spp. and Phomopsis spp., found in 0.8 and $17.5 \%$ of initial necrotic lesions (Table 2), need further morphological and molecular study.

All the fungal taxa which occurred frequently (Table 3) were detected both in initial necrotic lesions colonized by $H$. fraxineus and in those from which $H$. fraxineus was not isolated. From $26.7 \%$ of necrotic lesions, only $H$. fraxineus was isolated. Besides this, $H$. fraxineus was isolated together with one other fungus (from $23.6 \%$ of necrotic lesions), with two other fungi $(8.3 \%)$ or three other fungi $(0.6 \%)$. Diaporthe eres $(8.1 \%)$, A. alternata $(7.5 \%)$, Phomopsis spp. (3.9\%), D. mutila (3.6\%), F. avenaceum (3.6\%), F. lateritium (2.2\%) and A. pullulans $(1.4 \%)$ were the most common. Only one species, i.e. Diaporthe eres (from $8.3 \%$ of necrotic lesions), D. mutila (6.4\%), Phomopsis spp. (4.7\%), F. lateritium (3.1\%), F. avenaceum (1.7\%), A. alternata (0.8\%), V. cypri (0.5\%), L. corticola $(0.3 \%)$ and P. exigua $(0.3 \%)$, was isolated from $26.1 \%$ of necrotic lesions where $H$. fraxineus was not found. Two to four fungal species presented in Table 2 were isolated from the remaining $(14.7 \%)$ necrotic lesions.

There were 41 fungal taxa identified in 360 samples of dead apical parts of stems and twigs, based on the occurrence of fruit bodies and sporulation in situ (Table 2). Fruit bodies appeared on $91.2 \%$ of samples. The number of fungal taxa from each forest site ranged from 15 (Nowy Targ) to 26 (Miechów) (Table 4). Sørensen similarity indices for fungal communities between sites were high with an average of 0.80 (Table 6). Most species belonged to the Ascomycota. They formed ascomata $(25.6 \%$ of fungi), conidiomata $(64.1 \%)$ or both $(7.7 \%)$. Peniophora cinerea represented the Basidiomycota and formed flat, crust-like fruit bodies on $2.6 \%$ of samples (Table 2). Six taxa, Diaporthe eres, Diplodia mutila, Lophiostoma corticola, Phomopsis spp., Sirodothis sp. and Valsa cypri, were 
Fig. 2 Configuration plot represents the association between fungal community composition in initial necrotic lesions on living stems and twigs of $F$. excelsior and forest site location. The results of correspondence analysis frequency $>5 \%$. The directions account presented the greatest deviation from independence characterize the taxa with

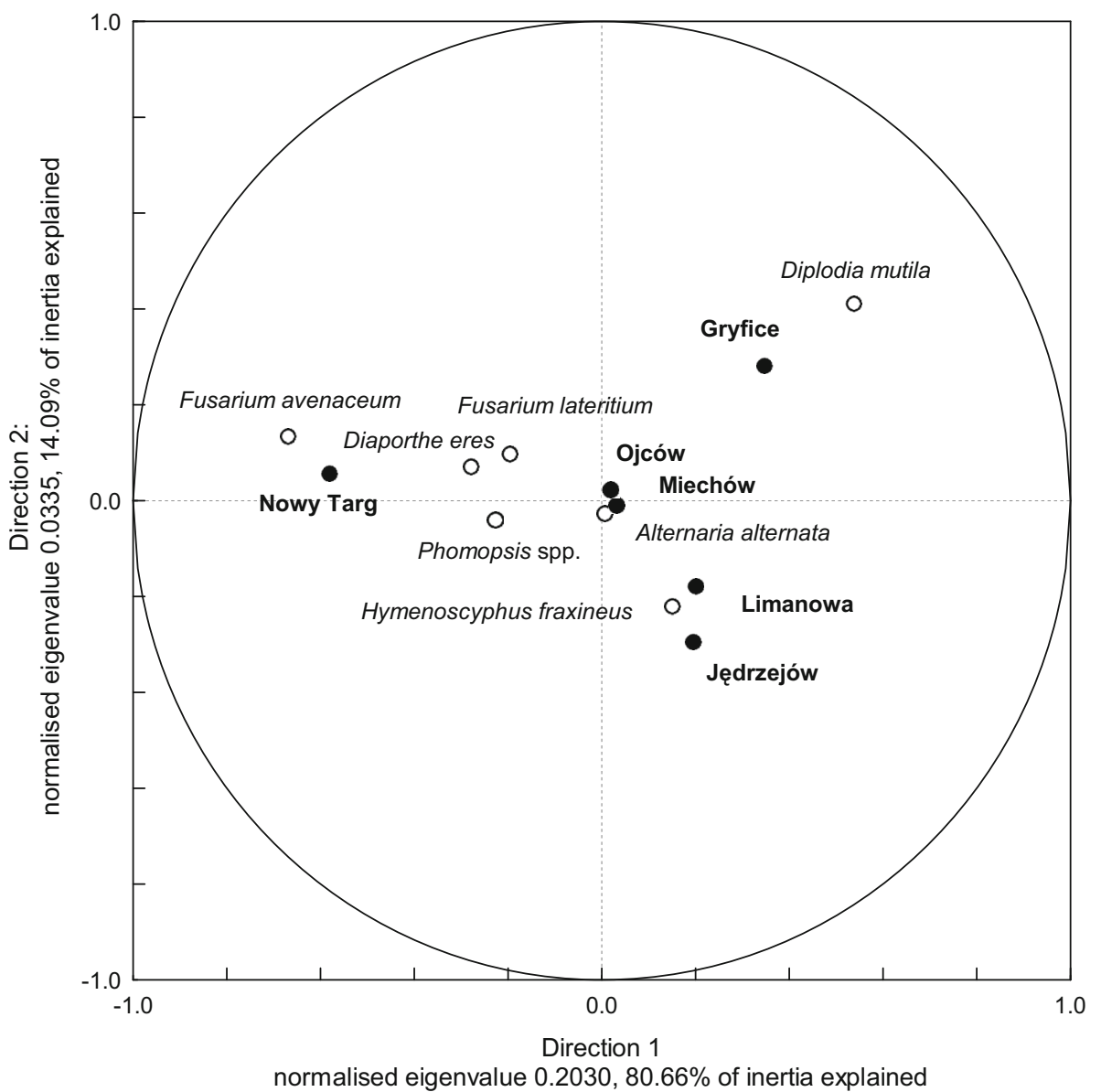

present in more than $5 \%$ of samples from all six forest sites (Table 4). Only fungi of these six taxa formed fruit bodies on material from all six sites. The frequency of fruit bodies differed between sites (Table 4). No apothecia of $H$. fraxineus were observed. On eight $(2.2 \%)$ samples, on wood exposed after necrosis and disintegration of the bark, this fungus formed a pseudosclerotial plate with phialides of its anamorph, Ch. fraxinea (Table 2). The highest frequency of $D$. eres and Phomopsis spp. occurred at the Nowy Targ site, of D. mutila at the Gryfice site, and of $V$. cypri at the Jędrzejów site (Table 4). Intense sporulation of the dark-pigmented fungi, Alternaria alternata, Cladosporium cladosporioides and Epicoccum nigrum, caused black discoloration of the dead apical parts of twigs. Melanomma pulvis-pyrius, Mollisia cf. cinerea and Teichospora obducens formed ascomata on wood exposed after disintegration of the bark. Species of Neonectria occurred usually in areas with local hypertrophies or cankers. Fusarium avenaceum and $F$. lateritium formed sporodochia incidentally, which were absent on the initial necrotic lesions. Fusarium avenaceum was found once producing perithecia (teleomorph: Gibberella avenacea). The wood in stems colonized by Peniophora cinerea showed symptoms of white rot.
There were, in total, 71 fungal taxa detected in 720 samples with initial and advanced necroses on stems and twigs (Table 1). Only 18 fungal taxa were detected in both initial necrotic lesions and dead apical parts of stems and twigs. Sørensen qualitative similarity index for both fungal communities was low (0.24), while Sørensen quantitative index was, however, relatively high (0.79). Among the more common species, A. alternata, $F$. avenaceum, $F$. lateritium and $H$. fraxineus were more frequent in the former and D. mutila, L. corticola and V. cypri in the latter type of sample material. Diaporthe eres and Phomopsis spp. were similarly frequent in the two types of material.

Relationships between fungal community composition, for species which exceeded $5 \%$ threshold of frequency, and forest site were graphically presented in normalized coordinates (Figs. 2, 3) as the results of correspondence analysis (CA). The analysis showed that only two directions explained the large part of total inertia $94.75 \%$ $\left(\chi^{2}=90.652\right)$ in fungal community composition at the initial necrotic stage and $83.48 \%\left(\chi^{2}=102.68\right)$ inertia at the advanced necrotic stage. The greatest distances between points were observed on main direction (direction 1) which are predominant projections of the latitude (compare Fig. 1). 
Fig. 3 Configuration plot represents the association between fungal community composition in dead apical parts of stems and twigs of $F$. excelsior and forest site location. The results of correspondence analysis characterize the taxa with frequency $>5 \%$. The directions account presented the greatest deviation from independence

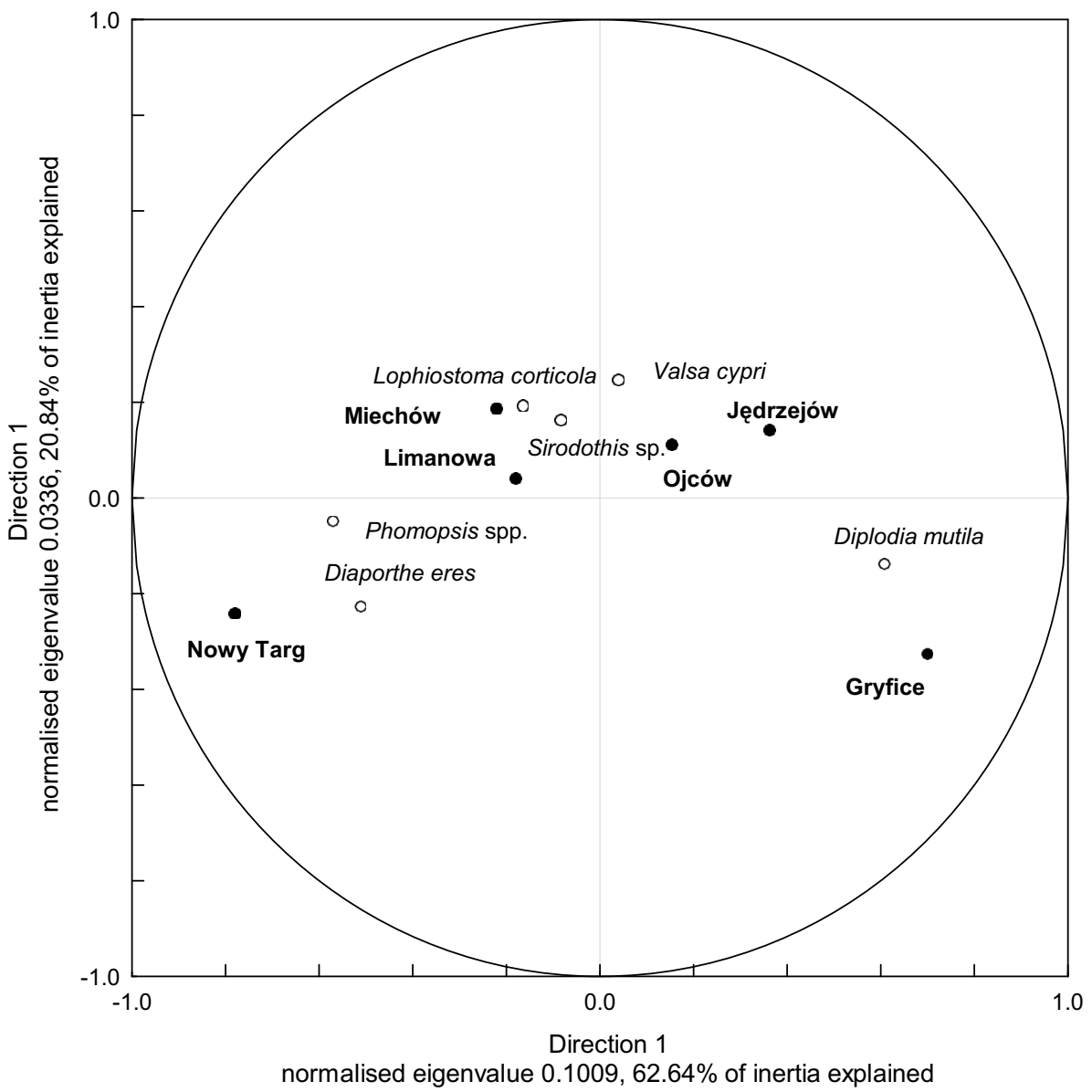

Table 5 Sørensen indices of similarity between fungal communities in initial necrotic lesions on living stems and twigs of $F$. excelsior from different forest sites

\begin{tabular}{llllll}
\hline Forest site & Nowy Targ & Gryfice & Jędrzejów & Miechów & Ojców \\
\hline Gryfice & 0.89 & & & & \\
Jędrzejów & 0.73 & 0.76 & & & \\
Miechów & 0.78 & 0.87 & 0.79 & & \\
Ojców & 0.86 & 0.94 & 0.74 & 0.83 & \\
Limanowa & 0.77 & 0.79 & 0.86 & 0.83 & 0.79 \\
\hline
\end{tabular}

The results of CA for the initial necrotic lesions showed that the greatest inertia in fungal community was due to $D$. mutila and $F$. avenaceum, which jointly contributed to $56.3 \%$ of the total inertia, and characterized the Gryfice and Nowy Targ site, respectively (Fig. 2). However, the greatest effect for the dead apical parts of stems and twigs in fungal community was due to D. eres, D. mutila and Phomopsis spp., which jointly contributed to $87 \%$ of inertia. D. eres and Phomopsis spp. showed the strong relationship to the Nowy Targ site and D. mutila to the
Table 6 Sørensen indices of similarity between the fungal communities on dead apical parts of stems and twigs of $F$. excelsior from different forest sites

\begin{tabular}{llllll}
\hline Forest site & Nowy Targ & Gryfice & Jędrzejów & Miechów & Ojców \\
\hline Gryfice & 0.83 & & & & \\
Jędrzejów & 0.79 & 0.73 & & & \\
Miechów & 0.82 & 0.83 & 0.88 & & \\
Ojców & 0.80 & 0.81 & 0.84 & 0.92 & \\
Limanowa & 0.72 & 0.65 & 0.77 & 0.75 & 0.79 \\
\hline
\end{tabular}

Gryfice site (Fig. 3). This suggests geographical relatedness for each of these fungal species.

\section{Discussion}

\section{Fungal diversity}

The USDA database lists 308 fungal species occurring on F. excelsior (after Pautasso et al. 2013). Considering this, 
the detection of 71 taxa on six sites located up to $600 \mathrm{~km}$ apart in Poland suggests a high diversity of fungi colonizing ash stems and twigs. A similarly high diversity of fungi on ash with dieback has been recorded by others. In Sweden, Bakys et al. (2009a) identified 56 fungal taxa on shoots of 20- to 30-year-old F. excelsior trees with various dieback symptoms, and in New Zealand, Chen (2012) identified 90 fungal taxa in bark and wood or buds of symptomless twigs of 60- to 70-year-old F. excelsior. In contrast, the base of dead twigs was colonized by only 22 species in healthy, naturally pruned $F$. excelsior trees (Butin and Kowalski 1986).

Despite the diversity of fungi, only a few species occurred with high frequency. Similar results were reported from Sweden (Bakys et al. 2009a, b). Most species that occurred commonly in this study have been found on stems and twigs of $F$. excelsior in various habitats (Butin and Kowalski 1986; Griffith and Boddy 1988, 1990, 1991; Lygis et al. 2005; Bakys et al. 2009a; Chen 2012; Davydenko et al. 2013).

Correspondence analysis revealed significant effects of locality on the frequency of some fungi. The strongest effect was recorded at the Gryfice site, which is in the north of Poland, close to the Baltic Sea, and at the Nowy Targ site, which is in the south, close to the Tatra Mountains. Different climatic conditions at these two sites seem to be the driving force for geographical specialization in these fungi (Table 1). For example, at the Nowy Targ site, $D$. mutila occurred only sporadically. This was the only sampling site located in a mountain region, where annual temperatures are lowest. Since $D$. mutila is a mesophile, with optimal temperature requirement of $25-28^{\circ} \mathrm{C}$, it seems to avoid colder sites (Luque 1989). Rainfall was the second important factor which differentiated the climatic conditions on different sites. The highest average rainfall was recorded at the Nowy Targ site (Table 1). According to correspondence analysis, such conditions favoured $D i$ apothe eres and Phomopsis spp. (Figs. 2, 3). Fungal community structure could be also affected by tree species composition in the stand on a particular site. Such fungi as Cryptosphaeria eunomia, Camarosporium orni, Gloeosporidiella turgida and Hymenoscyphus fraxineus are associated only or mainly with Fraxinus sp. Other fungi may occur on a few species of plants (Coleophoma empetri, Diplodia mutila, Valsa cypri) or may have very wide host range (Alternaria alternata, Aureobasidium pullulans, Cladosporium cladosporioides, Diaporthe spp., Epicoccum nigrum, Fusarium spp.). A more diverse composition of plants at a forest site could contribute to the occurrence of the wider spectrum of fungi colonizing $F$. excelsior.

Some fungi are frequent in symptomless stems and twigs of $F$. excelsior as endophytes. This may therefore allow them to develop fruit bodies on necrotic lesions after $H$. fraxineus infection. Alternaria alternata, Fusarium spp. and Phomopsis spp. are generally reported as the most common endophytes in ash bark and wood (Griffith and Boddy 1991; Kowalski and Kehr 1992; Sieber 2007; Bakys et al. 2009a; Chen 2012). In symptomless branch bases, these three taxa were more frequent in F. excelsior than in ten other tree species examined (Kowalski and Kehr 1992). Alternaria alternata was detected in $22.9 \%$, Phomopsis in $51.4 \%$ and Fusarium, which occurred exclusively in $F$. excelsior, in $5.7 \%$ of branches (Kowalski and Kehr 1992). In Sweden, A. alternata was very frequent in both symptomless, healthy-looking shoots and in shoots with initial and advanced necroses (Bakys et al. 2009a). In the Ukraine, A. alternata occurred in symptomatic shoots at a frequency more than twice that in the present study, but was absent from symptomless, healthy-looking shoots (Davydenko et al. 2013). Artificial inoculation of 1-yearold $F$. excelsior seedlings showed that A. alternata only occasionally participates in the formation of stem necrosis (Bakys et al. 2009a).

The two different fungal detection methods allowed identification of the primary colonizers, which either immediately follow $H$. fraxineus infection or infect the ash tree independently of $H$. fraxineus, and secondary colonizers inhabiting stems in the advanced disease stage (Table 2). According to the Sørensen quantitative index (0.24), the species similarity of fungi in initial necrotic lesions and on dead apical parts of stems and twigs was relatively low. One of the reasons for these community differences may be the method of isolation, which favoured fungi from inner bark and sapwood and probably missed the fungi living in the outer bark. In contrast, fruiting bodies were probably most often formed on the outer bark in dead apical parts.

\section{Occurrence of Hymenoscyphus fraxineus}

Hymenoscyphus fraxineus was the most frequent species in initial necrotic lesions. Its role as the main pathogenic agent of the current ash dieback epidemic in Europe has been confirmed in this and several other studies and is beyond dispute (Kowalski 2006; Kowalski and Holdenrieder 2009b; Bakys et al. 2009b; Husson et al. 2011; Kirisits et al. 2012; Gross et al. 2014). The necrotic lesions formed in the initial stage of disease on twigs and young side branches were typical, and similar to those described for $H$. fraxineus after natural infections (Kowalski and Holdenrieder 2008) and artificial inoculations (Kowalski and Holdenrieder 2009b; Bakys et al. 2009a, b).

Detection of $H$. fraxineus in only $59.2 \%$ of lesions is likely to have had a number of causes, including its slow growth and antagonistic activity of other colonizers of the 
lesions, which were able to compete successfully for nutrients and space or acted through antibiosis. Hymenoscyphus fraxineus grows slowly and, on artificial media, seems to survive through production of fungistatic viridin, which inhibits the growth of accompanying fastgrowing fungi (Grad et al. 2009). The relationships between fungi identified on stems in situ are not well known. Successful competition by the accompanying fungi, in situ, may eliminate or inhibit growth of $H$. fraxineus on artificial medium in vitro. Moreover, successful isolation of $H$. fraxineus depends on the age of the necrotic lesion. In the host tissues killed by the pathogen, the opportunistic fungi may develop more rapidly (Gross et al. 2014). After artificial inoculation, $H$. fraxineus was reisolated from $100 \%$ of lesions after 2 months and from $71.4 \%$ of lesions after 12 months (Kowalski and Holdenrieder 2009b). After natural infection, the pathogen was isolated from $88.7 \%$ of initial lesions and from $29.5 \%$ of advanced necroses (Kowalski 2009). Failures in isolation of $H$. fraxineus after natural infection from advanced necroses have also been reported elsewhere. In Sweden, $H$. fraxineus was detected only occasionally in both initial and advanced necroses after natural infection (Bakys et al. 2009a), and it was recorded in only 17-64\% of lesions depending on the habitat (Bengtsson et al. 2014). In Ukraine, $H$. fraxineus was detected only in $5.6 \%$ of symptomatic shoots (Davydenko et al. 2013). In the context of the latter, it must be emphasized that the age of necrotic lesions described in our paper as 'initial' is not known. Considering their visually recorded appearance in the sampling period, i.e. in May-June, we presume that they had been formed after the completion of the previous year's annual growth. The necrotic tissues were not sunken in comparison with the surrounding tissues. The reasons presented above might have contributed to the rather low isolation success of $H$. fraxineus.

The low rate of isolation of $H$. fraxineus suggests that other factors may be involved and contribute to the formation of necroses. Husson et al. (2011), who detected Hymenoscyphus species in $80 \%$ of symptomatic $F$. excelsior samples using molecular methods and $\mathrm{Hy}$ menoscyphus-specific PCR primers, concluded that the remaining $20 \%$ of lesions may have been the result of damage by abiotic factors or infection by other pathogenic fungi. Previously, before the invasion of $H$. fraxineus, similar lesions on branches and stems of ash trees could be caused by Hysterographium fraxini (Zogg 1944; Prihoda 1982; Cannon 1999). This fungus has not been recorded during current $H$. fraxineus epidemics either in Poland (Kowalski 2001; Przybył 2002; Kowalski and Łukomska 2005; Kowalski and Czekaj 2010) or in Sweden (Bakys et al. 2009ab). In Ukraine, H. fraxini was detected in only $5.6 \%$ of symptomatic shoots (Davydenko et al. 2013).

\section{Occurrence of other frequent fungal species}

The present and previous studies show that symptomatic $F$. excelsior shoots may be colonized by Fusarium spp., more often by $F$. avenaceum and $F$. lateritium and less often by F. solani (Przybył 2002; Kowalski and Łukomska 2005; Ioos et al. 2009; Bakys et al. 2009a; Davydenko et al. 2013). Fusarium lateritium is well known on $F$. excelsior in association with Pseudomonas savastanoi pv. fraxini, the causal agent of the bacterial ash canker (Riggenbach 1956). Infection of ash twigs by $F$. lateritium may also start from dead buds colonized by the ash bud moth, Prays fraxinella. Colonization may result in the formation of smooth red-brown swellings on the stems, with small cracks at their margin (Janse 1981). Fusarium lateritium is also one of the main primary colonizers of the superficial tissues of living and dead ash twigs (Griffith and Boddy 1991). The high frequency of Fusarium species, particularly in symptomless ash tissues, may result from elimination of other fungal colonizers by production of antifungal metabolites (Riggenbach 1956; Griffith and Boddy 1991; Lysøe et al. 2014). Studies on F. avenaceum and $F$. lateritium did not provide any evidence for their pathogenicity to F. excelsior (Bakys et al. 2009a).

Diaporthe (anamorph: Phomopsis) species have often been reported as plant pathogens, non-pathogenic endophytes or saprobes, commonly isolated from a wide range of hosts (Kowalski and Kehr 1992; Sieber 2007; Gomes et al. 2013). They produce lignocellulolytic enzymes and interesting secondary metabolites with antibiotic activity (Gomes et al. 2013). Although $H$. fraxineus is an invasive fungus, it does not eliminate Diaporthe/Phomopsis from the ash stems and twigs on which the latter produces fruit bodies. It can be concluded that $H$. fraxineus, by causing early necrosis, favours colonization and fructification by Diaporthe. It is so far impossible to state if this situation allows the Diaporthe a chance to increase the size of necrotic lesions. This depends on specialization and adaptation in Diaporthe/Phomopsis. Some species of this complex can be therefore either harmless endophytes or pathogenic depending on the host health status (Uecker 1988; Gomes et al. 2013). Diaporthe/Phomopsis fungi have often been classified as host specific (Udayanga et al. 2011; Gomes et al. 2013). Species recorded so far on Fraxinus included mostly Ph. controversa, Ph. platanoidis and Ph. scobina (Butin and Kowalski 1986; Griffith and Boddy 1988, 1990; Przybył 2002; Kowalski and Czekaj 2010; Gomes et al. 2013). Recent studies have shown, however, that although some Diaporthe species are host specific, a great number of species are able to colonize diverse hosts (Gomes et al. 2013). Diaporthe eres is the species currently found most often on diseased ash trees. It can live as a pathogen, endophyte or saprotroph and has a widespread 
distribution and broad host range (Udayanga et al. 2014). In some regions, it is considered an important pathogen with significance in plant health inspection and quarantine (Cline and Farr 2006; Udayanga et al. 2014).

Diplodia mutila (teleomorph: Botryosphaeria stevensii) is an ascomycetous fungus from the Botryosphaeriaceae with worldwide distribution (Alves et al. 2014). A wide host range has also been reported (Sutton 1980). Recently, however, confirmed hosts of D. mutila have included only Chamaecyparis lawsoniana, Fraxinus spp., Malus spp., Populus spp., Taxus baccata and Vitis vinifera (Phillips et al. 2013; Alves et al. 2014). Molecular characterization of Polish isolates of this fungus were reported by Kraj et al. (2013), who showed that isolates of D. mutila from $F$. excelsior in Poland were genetically very similar to isolates from other regions of the world. The close similarity of all isolates from $F$. excelsior indicates the possibility of host specialization in the fungus. Kraj et al. (2013) also showed that isolates from $F$. excelsior were phylogenetically quite distant from isolates from $F$. angustifolia. Alves et al. (2014) showed that isolates of D. mutila from $F$. angustifolia differed genetically and morphologically and the fungus was designated as Diplodia fraxini. In Europe, $D$. mutila was not recorded among frequent colonizers of $F$. excelsior before $H$. fraxineus appeared (Sutton 1980; Butin and Kowalski 1986; Griffith and Boddy 1988). Ten years after the appearance of $H$. fraxineus in Poland D. mutila was still detected only rarely, although it was widely distributed (Przybył 2002). It has now become more frequent on ash trees with dieback symptoms in Poland (Kowalski and Łukomska 2005; Kowalski and Czekaj 2010) and other countries in Europe (Lygis et al. 2005; Cech 2006; Bakys et al. 2009a; Gross et al. 2014). The present results confirm earlier studies. It seems that $H$. fraxineus may increase the susceptibility of $F$. excelsior to colonization by $D$. mutila. Przybył (2002) confirmed the pathogenicity of $D$. mutila on 2-year-old $F$. excelsior saplings. Therefore, it cannot be discounted that $D$. mutila contributes to the enlargement of necroses primarily caused by $H$. fraxineus or may cause separate necroses. The latter would explain the absence of $H$. fraxineus in some of the initial necrotic lesions that were analysed. Since D. mutila requires relatively high $\left(25-28{ }^{\circ} \mathrm{C}\right)$ temperature, global warming may increase its pathogenic role in ash stands (Luque 1989; Thompson et al. 2010).

Lophiostoma corticola (syn: Massarina corticola) has wide host and geographical range (Bose 1961; Farr et al. 1989; Liew et al. 2002; Chen 2012). It was not recorded in previous studies of ash twigs (Butin and Kowalski 1986; Griffith and Boddy 1988, 1990, 1991). Currently, it is found frequently on ash. In the Ukraine, this fungus was detected in litter, in ash petioles from the previous year (Davydenko et al. 2013). It was also detected in ash wood in Slovenia (Gherghel et al. 2014) and in the bark and buds of living ash branches in New Zealand (Chen 2012). The present results suggest that its frequency increases in stems and twigs with advanced necrosis, which categorizes the fungus rather as a secondary invader or saprotroph.

Valsa cypri (anamorph: Cytospora pruinosa, Cytophoma pruinosa) occurs in Asia, Europe and North America on plants of the family Oleaceae, including Fraxinus, Ligustrum, Olea and Syringa, and also of the families Moraceae and Celtidaceae (Spielman 1985; Farr et al. 1989; Hayova and Minter 1998; Fotouhifar et al. 2010). This fungus was often found on deteriorated white ash trees ( $F$. americana) in USA (Silverborg and Brandt 1957; Ross 1964). Ross (1964) concluded that such trees must first have been predisposed to infection by the fungus and that the predisposition could have resulted from drought. Since $V$. cypri occurred rarely in initial necrotic lesions but frequently in dead stems and twigs, it may be assumed that the predisposition can also result from earlier infection by $H$. fraxineus.

Pleurophoma pleurospora and Sirodothis sp. are other species that seem to benefit from prior infection by $H$. fraxineus. Both fungi occurred more frequently in stems and twigs with advanced necroses. The former (anamorph: unknown) occurs on branches and bare wood of trees and shrubs (Sutton 1980; de Gruyter et al. 2010). The latter is an anamorph of the discomycetous genus Tympanis (Johnston et al. 2014).

Among the species that occur less frequently on ash trees, Nectria cinnabarina, Neonectria coccinea, N. galligena, Phoma exigua and Valsa ambiens are known to be pathogenic on ash (Sinclair and Lyon 2005a, b; Schmitz et al. 2006).

Further pathogenicity tests are needed to establish the role of particular fungal species in the pathogenesis of ash dieback. The significance of colonized organs as reservoirs of inoculum for ash and other tree species also needs to be studied. In such studies, emphasis should be placed on the most frequent species of fungi, including D. mutila, Diaporthe spp., Fusarium spp. and V. cypri. Since $H$. fraxineus does not form fruit bodies on symptomatic ash stems and twigs, there is no threat of dissemination of the pathogen from these ash tissues.

Ash dieback has implications for fungal biodiversity. In the short term, some initial or secondary fungal colonizers may benefit from earlier infection of $F$. excelsior by $H$. fraxineus. In the long term, however, the possible extinction or drastic reduction of the European ash population will cause changes in the habitat followed by decrease in occurrence of ash-specific fungi (Pautasso et al. 2013). Changes in biodiversity will include not only the fungi. Occurrence of ash dieback may also affect other organisms associated with or dependent on European ash (Jönsson and Thor 2012). 


\section{Conclusions}

Details of fungal occurrence on ash trees with symptoms of dieback are reported. The results showed that, in necrotic ash tissue, numerous fungi may occur, although only a few species were very frequent. Mycological analysis, by classical isolation of fungi from ash stems and twigs with initial necrotic lesions, confirmed $H$. fraxineus as the main causal agent of the current epidemic of ash dieback. Failure to detect the pathogen in some samples may have resulted from difficulties associated with isolation on artificial media or from the pathogen's absence in necroses caused by other fungi. A large group of fungi appear to benefit from prior infection of ash trees by invasive $H$. fraxineus. Symptomatic stems and twigs were often colonized by fungi that occurred less frequently in the early stages of ash diseases in the past, before the current $H$. fraxineus epidemic. This group includes the endophytes Alternaria, Fusarium and Diaporthe (Phomopsis), and the facultative parasite Diplodia mutila, which infect ash in favourable conditions. Hymenoscyphys fraxineus did not form apothecia on dead apical parts of stems and twigs confirming that these plant tissues do not contribute to the reservoir of inoculums of $H$. fraxineus. The sporadic occurrence of the anamorph stage of $H$. fraxineus, Chalara fraxinea, on dead stems is not significant for disease development because conidia are not able to infect. Fungi that formed fruit bodies most frequently on the dead apical parts of stems and twigs were: Diaporthe eres, Diplodia mutila, Lophiostoma corticola, Phomopsis spp., Sirodothis sp. and Valsa cypri. Some of these are facultative parasites, therefore leaved in the forest of dead ashes which are well colonized by the mentioned fungi may represent a noticeable threat to young or stressed and weakened ash trees, or even to other tree species since some of the fungi species possess broad host spectrum.

Acknowledgments Research was conducted between 2012 and 2015 as part of a project supported by the National Science Centre, decision no. DEC-2011/03/B/NZ9/00078. The authors express their gratitude to the Heads of Forest Districts and Ojców National Park for their help during research. We thank Krzysztof Leszczyński for his help with statistical analyses and two anonymous reviewers for constructive comments on the manuscript.

Open Access This article is distributed under the terms of the Creative Commons Attribution 4.0 International License (http://creative commons.org/licenses/by/4.0/), which permits unrestricted use, distribution, and reproduction in any medium, provided you give appropriate credit to the original author(s) and the source, provide a link to the Creative Commons license, and indicate if changes were made.

\section{References}

Altschul SF, Madden TL, Schäffer AA, Zhang J, Zhang Z, Miller W, Lipman DJ (1997) Gapped BLAST and PSI-BLAST: a new generation of protein database search programs. Nucleic Acids Res 25:3389-3402

Alves A, Linaldeddu BT, Deidda A, Scanu B, Phillips AJL (2014) The complex of Diplodia species associated with Fraxinus and some other woody hosts in Italy and Portugal. Fungal Divers 67:143-156

Amar A, Smith KW, Butler S, Lindsell JA, Hewson CM, Fuller RJ, Charman EC (2010) Recent patterns of change in vegetation structure and tree composition of British broadleaved woodland: evidence from large-scale surveys. Forestry 83:345-356

Bakys R, Vasaitis R, Barklund P, Thomsen IM, Stenlid J (2009a) Occurrence and pathogenicity of fungi in necrotic and nonsymptomatic shoots of declining common ash (Fraxinus excelsior) in Sweden. Eur J For Res 128:51-60

Bakys R, Vasaitis R, Barklund P, Ihrmark K, Stenlid J (2009b) Investigations concerning the role of Chalara fraxinea in declining Fraxinus excelsior. Plant Pathol 58:284-292

Baral H-O, Bemmann M (2014) Hymenoscyphus fraxineus vs. Hymenoscyphus albidus: a comparative light microscopic study on the causal agent of European ash dieback and related foliicolous, stroma-forming species. Mycology 5(4):228-290

Baral H-O, Queloz V, Hosoya T (2014) Hymenoscyphus fraxineus, the correct scientific name for the fungus causing ash dieback in Europe. IMA Fungus 5(1):79-80

Bengtsson SBK, Barklund P, von Brömssen C, Stenlid J (2014) Seasonal pattern of lesion development in diseased Fraxinus excelsior infected by Hymenoscyphus pseudoalbidus. PLoS ONE 9(4):e76429. doi:10.1371/journal.pone.0076429

Boerema GH, Gruyter J, de Noordeloos ME, Hamers MEC (2004) Phoma identification manual. Differentiation of specific and infra-specific taxa in culture. CABI Publishing, CAB International Wallingford, Oxfordshire

Bose SK (1961) Studies on Massarina Sacc. and related genera. J Phytopathol 41:151-213

Butin H, Kowalski T (1986) Die natürliche Astreinigung und ihre biologischen Voraussetzungen. III. Die Pilzflora von Ahorn, Erle, Birke, Hainbuche und Esche. Eur J For Pathol 16(3):129-138

Cannon PF (1999) Hysterographium fraxini. IMI Descr Fungi Bacteria 141:1406

Cech T (2006) Eschenschäden in Österreich. Forstschutz Aktuell 37:18-20

Chandelier A, André F, Laurent F (2010) Detection of Chalara fraxinea in common ash (Fraxinus excelsior) using real time PCR. For Pathol 40:87-95

Chen J (2012) Fungal community survey of Fraxinus excelsior in New Zealand. Dissertation, Swedish University of Agricultural Sciences, Uppsala

Clark JR (2013) Adaptation of ash (Fraxinus excelsior L.) to climate change. Dissertation, Bangor University, UK

Cline ET, Farr DF (2006) Synopsis of fungi listed as regulated plant pests by the USDA animal and plant health inspection service: notes on nomenclature, disease, plant hosts, and geographic distribution. Plant Health Progress. doi:10.1094/PHP-2006-0505-01-DG

Davydenko K, Vasaitis R, Stenlid J, Menkis A (2013) Fungi in foliage and shoots of Fraxinus excelsior in eastern Ukraine: a first report on Hymenoscyphus pseudoalbidus. For Pathol 43:462-467

de Gruyter J, Woudenberg JH, Aveskamp MM, Verkley GJ, Groenewald JZ, Crous PW (2010) Systematic reappraisal of species in Phoma section Paraphoma, Pyrenochaeta and Pleurophoma. Mycologia 102(5):1066-1081

Dobrowolska D, Hein S, Oosterbaan A, Wagner S, Clark JR, Skovsgaard JP (2011) A review of European ash (Fraxinus excelsior L.): implications for silviculture. Forestry 84:133-148

Domsch KH, Gams W, Anderson TH (1980) Compendium of soil fungi. Academic Press, London 
Ellis MB (1971) Dematiaceous hyphomycetes. CMI, Kew, Surry, England

Ellis MB, Ellis JP (1985) Microfungi on land plants. Croom Helm, London, Sydney

Farr DF, Bills GF, Chamuris GP, Rossman AY (1989) Fungi on plants and plant products in the United States. APS Press, St. Paul (Minnesota)

Fotouhifar KB, Hedjaroude GA, Leuchtmann A (2010) ITS rDNA phylogeny of Iranian strains of Cytospora and associated teleomorphs. Mycologia 102(6):1369-1382

Gardes M, Bruns TD (1993) ITS primers with enhanced specificity for basidiomycetes- application of the identification of mycorrhizae and rusts. Mol Ecol 2:113-118

Gherghel F, Fussi B, Donges K, Haustein M, Jakob KM, Müller K, Piškur B, Hauptman T, Lenz HD, Konnert M, Kost G, Rexer K-H (2014) The development of a species-specific test to detect Hymenoscyphus pseudoalbidus in ash tissues. For Pathol 44:137-144

Glen M, Tommerup IC, Bougher NL, O’Brien PA (2001) Interspecific and intraspecific variation of ectomycorrhizal fungi associated with Eucalyptus ecosystems as revealed by ribosomal DNA PCR - RFLP. Mycol Res 105:843-858

Gomes RR, Glienke C, Videira SIR, Lombard L, Groenewald JZ, Crous PW (2013) Diaporthe: a genus of endophytic, saprobic and plant pathogenic fungi. Persoonia 31:1-41

Grad B, Kowalski T, Kraj W (2009) Studies on secondary metabolite produced by Chalara fraxinea and its phytotoxic influence on Fraxinus excelsior. Phytopathologia 54:61-69

Griffith GS, Boddy L (1988) Fungal communities in attached ash (Fraxinus excelsior) twigs. Trans Br Mycol Soc 91(4):599-606

Griffith GS, Boddy L (1990) Fungal decomposition of attached angiosperm twigs. I. Decay community development in ash, beech and oak. New Phytol 116:407-415

Griffith GS, Boddy L (1991) Fungal decomposition of attached angiosperm twigs IV. Effect of water potential on interactions between fungi on agar and in wood. New Phytol 117:633-641

Gross A, Holdenrieder O, Pautasso M, Queloz V, Sieber TN (2014) Hymenoscyphus pseudoalbidus, the causal agent of European ash dieback. Mol Plant Pathol 15(1):5-21

Grove WB (1935) British stem- and leaf- fungi (Coelomycetes): a contribution to our knowledge of the Fungi imperfecti belonging to the Sphaeropsidales and the Melanconiales. Univ. Press, Cambridge

Hawksworth DL (2014) Possible house-keeping and other draft proposals to clarify or enhance the naming of fungi within the International Code of Nomenclature for algae, fungi, and plants (ICN). IMA Fungus 5:31-37

Hayova VP, Minter DW (1998) Valsa cypri. IMI Descr Fungi Bacteria 137:1367

Husson C, Scala B, Cael O, Frey P, Feau N, Ioos R, Marcais B (2011) Chalara fraxinea is an invasive pathogen in France. Eur J Plant Pathol 130:311-324

Ioos R, Kowalski T, Husson C, Holdenrieder O (2009) Rapid in planta detection of Chalara fraxinea by a real-time PCR assay using a dual-labelled probe. Eur J Plant Pathol 125:329-335

Janse JD (1981) The bacterial disease of ash (Fraxinus excelsior), caused by Pseudomonas syringae subsp. savastanoi pv. fraxini. I. History, occurrence and symptoms. Eur J For Pathol 11(5-6):306-315

Johnston PR, Seifert KA, Stone JK, Rossman AY, Marvanová L (2014) Recommendations on generic names competing for use in Leotiomycetes (Ascomycota). IMA Fungus 5(1):91-120

Jönsson MT, Thor G (2012) Estimating coextinction risks from epidemic tree death: affiliate lichen communities among diseased host tree populations of Fraxinus excelsior. PLoS ONE 7(9):e45701
Kearse M, Moir R, Wilson A, Stones-Havas S, Cheung M, Sturrock S, Buxton S, Cooper A, Markowitz S, Duran C, Thierer T, Ashton B, Mentjies P, Drummond A (2012) Geneious Basic: an integrated and extendable desktop software platform for the organization and analysis of sequence data. Bioinformatics 28(12):1647-1649

Kirisits T, Freinschlag C (2012) Ash dieback caused by Hymenoscyphus pseudoalbidus in a seed plantation of Fraxinus excelsior in Austria. J Agric Ext Rural Dev 4:184-191

Kirisits T, Kritsch P, Kräutler K, Matlakova M, Halmschlager E (2012) Ash dieback associated with Hymenoscyphus pseudoalbidus in forest nurseries in Austria. J Agric Ext Rural Dev 4:223-226

Kowalski $\mathrm{T}$ (2001) On the ash dieback. Trybuna Leśnika $\mathrm{Nr}$ 4(359):6-7 (in Polish)

Kowalski T (2006) Chalara fraxinea sp. nov. associated with dieback of ash (Fraxinus excelsior) in Poland. For Pathol 36:264-270

Kowalski T (2009) Expanse of Chalara fraxinea fungus in terms of ash dieback in Poland. Sylwan 10:668-674 (in Polish)

Kowalski T, Czekaj A (2010) Disease symptoms and fungi on dying ash trees (Fraxinus excelsior L.) in Staszów forest district stands. Leśne Prace Badawcze 71(4):357-368 (in Polish)

Kowalski T, Holdenrieder O (2008) Eine neue Pilzkrankheit an Esche in Europa. Schweiz. Z. Forstwes 159(3):45-50

Kowalski T, Holdenrieder O (2009a) The teleomorph of Chalara fraxinea. For Pathol 39:304-308

Kowalski T, Holdenrieder O (2009b) Pathogenicity of Chalara fraxinea. For Pathol 39:1-7

Kowalski T, Kehr RD (1992) Endophytic fungal colonization of branch bases in several forest tree species. Sydowia 44:137-168

Kowalski T, Łukomska A (2005) The studies on ash dying (Fraxinus excelsior L.) in the Włoszczowa Forest Unit stands. Acta Agrobot 59(2):429-440 (in Polish)

Kowalski T, Schumacher J, Kehr R (2010) Das Eschensterben in Europa: Symptome, Erreger und Empfehlungen für die Praxis. In: Dujesiefken D (Hrsg) Jahrbuch der Baumpflege, Haymarket Media Braunschweig, pp 184-195

Kraj W, Kowalski T (2014) Genetic variability of Hymenoscyphus pseudoalbidus dieback cause of European ash (Fraxinus excelsior L.). J Phytopathol 162:218-227

Kraj W, Kowalski T, Zarek M (2013) Structure and genetic variation of Diplodia mutila on declining ashes (Fraxinus excelsior) in Poland. J Plant Pathol 95(3):499-507

Lassauce A, Paillet Y, Jactel H, Bouget C (2011) Deadwood as a surrogate for forest biodiversity: meta-analysis of correlations between deadwood volume and species richness of saproxylic organisms. Ecol Indic 11:1027-1039

Liew ECY, Aptroot A, Hyde KD (2002) An evaluation of the monophyly of Massarina based on ribosomal DNA sequences. Mycologia 94(5):803-813

Luque J (1989) Effects of temperature, culture medium and $\mathrm{pH}$ on colony growth of Diplodia mutila Fr. apud Mont. Anales Jard Bot Madrid 46(1):215-221 (in Spanish)

Lygis V, Vasiliauskas R, Larsson KH, Stenlid J (2005) Woodinhabiting fungi in stems of Fraxinus excelsior in declining ash stands of northern Lithuania, with particular reference to Armillaria cepistipes. Scand J For Res 20:337-346

Lysøe E, Harris LJ, Walkowiak S, Subramaniam R, Divon HH, Riiser ES, Llorens C, Gabaldón T, Kistler HC, Jonkers W, Kolseth AK, Nielsen KF, Thrane U, Frandsen RJ (2014) The genome of the generalist plant pathogen Fusarium avenaceum is enriched with genes involved in redox, signaling and secondary metabolism. PLoS ONE 9(11):e112703. doi:10.1371/journal.pone.0112703

Magurran AE (1988) Ecological diversity and its Measurement. Princeton University Press, Princeton

Marigo G, Peltier J-P, Girel J, Pautou G (2000) Success in the demographic expansion of Fraxinus excelsior L. Trees 15:1-13 
McKinney LV, Nielsen LR, Hansen JK, Kjær ED (2011) Presence of natural genetic resistance in Fraxinus excelsior (Oleaceae) to Chalara fraxinea (Ascomycota): an emerging infectious disease. Heredity 106:788-797

Pautasso M, Aas G, Queloz V, Holdenrieder O (2013) European ash (Fraxinus excelsior) dieback: a conservation biology challenge. Biol Cons 158:37-49

Phillips AJL, Alves A, Abdollahzadeh J, Slippers B, Wingfield MJ, Groenewald JZ, Crous PW (2013) The Botryosphaeriaceae: genera and species known from culture. Stud Mycol 76:51-167

Prihoda A (1982) Hubove nakazy jasenov po napadnuti lykokazem jasenovym Hylesinus fraxini (Panzer) [Fungi infections of ash trees after attack by the common ash bark beetle Hylesinus fraxini (Panzer)]. Lesn Čas 28(1):19-27

Przybył K (2002) Fungi associated with necrotic apical parts of Fraxinus excelsior shoots. For Pathol 32:387-394

Queloz V, Grünig CR, Berndt R, Kowalski T, Sieber TN, Holdenrieder O (2011) Cryptic speciation in Hymenoscyphus albidus. For Pathol 41(2):133-142

Riggenbach A (1956) Untersuchung über den Eschenkrebs. J Phytopathol 27(1):1-40

Ross EW (1964) Cankers associated with ash dieback. Phytopathology $54: 272-275$

Schmitz S, Zini J, Etienne M, Moreau J-M, Chandelier A, Cavelier M (2006) Effectiveness of thiophanate-methyl, trifloxystrobin and vinclozolin on canker caused by Phoma exigua Desm. on ash tree seedlings. Biotechnol Agron Soc Environ 10(1):25-31

Schumacher J, Kehr R, Leonhard S (2010) Mycological and histological investigations of Fraxinus excelsior nursery saplings naturally infected by Chalara fraxinea. For Pathol 40:419-429

Sieber TN (2007) Endophytic fungi in forest trees: are they mutualists? Fungal Biol Rev 21(2):75-89

Silverborg SB, Brandt RW (1957) Association of Cytophoma pruinosa with dying ash. For Sci 3:75-78

Sinclair WA, Lyon HH (2005a) Diseases of trees and shrubs, 2nd edn. Cornell University Press, Ithaca

Sinclair WA, Lyon HH (2005b) Diseases of trees and shrubs. Cornell University Press, Ithaca

Sivanesan A (1984) The bitunicate Ascomycetes and their anamorphs. J. Cramer Ltd, Vaduz
Skovsgaard JP, Thomsen IM, Skovgaard IM, Martinussen T (2010) Associations among symptoms of dieback in even-aged stands of ash (Fraxinus excelsior L.). For Pathol 40:7-18

Spielman LJ (1985) A monograph of Valsa on hardwoods in North America. Can J Bot 63:1355-1378

StatSoft, Inc. (2011). STATISTICA (data analysis software system), version 10. www.statsoft.com

Sutton BC (1980) The Coelomycetes. Fungi Imperfecti with Pycnidia, Acervuli and Stromata. Kew, Commonwealth Mycological Institute

Thompson S, Álvarez-Loayza P, Terborgh JW, Katul G (2010) The effects of plant pathogens on tree recruitment in the Western Amazon under a projected future climate: a dynamical systems analysis. J Ecol 98:1434-1446

Timmermann V, Børja I, Hietala AM, Kirisits T, Solheim H (2011) Ash dieback: pathogen spread and diurnal patterns of ascospore dispersal, with special emphasis on Norway. EPPO Bull 41:14-20

Udayanga D, Liu X, McKenzie EHC, Chukeatirote E, Bahkali AHA, Hyde KD (2011) The genus Phomopsis: biology, applications, species concepts and names of common phytopathogens. Fungal Divers 50:189-225

Udayanga D, Castlebury LA, Rossman AY, Chukeatirote E, Hyde KD (2014) Insights into the genus Diaporthe: phylogenetic species delimitation in the $D$. eres species complex. Fungal Divers 67:203-229

Uecker A (1988) A world list of Phomopsis names with notes on nomenclature, morphology and biology. Mycol Mem 13:1-231

Wallander E (2008) Systematics of Fraxinus (Oleaceae) and evolution of dioecy. Plant Syst Evol 273:25-49

Wardle P (1961) Biological flora of British Isles: Fraxinus excelsior L. J Ecol 49:739-751

White TJ, Bruns TD, Lee S, Taylor J (1990) Amplification and direct sequencing of fungal ribosomal RNA genes for phylogenetics. In: Innis MA, Gelfand DH, Sninsky JJ, White TJ (eds) PCR protocols: A guide to methods and applications. Academic Press, New York, pp 315-322

Zogg H (1944) Untersuchungen über die Gattung Hysterographium Corda, insbesondere über Hysterographium fraxini (Pers.) de Not. J Phytopathol 14:311-381 